\title{
Local Response to Conservation Practices in Use for the Protection of Tinau River, Nepal
}

Khet Raj Dahal and Hari Prasad Guragain

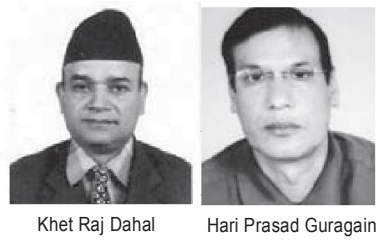

Abstract: A study was undertaken to identify the pressing problems in the Tinau River and to suggest ways to overcome the various problems such as pollution, riverbed extraction, bank erosion and threats to the foundation of bridges, etc. The study showed several problems responsible for deteriorating the health of the Tinau River. The Study suggests that the agencies and stakeholders should work together to counter the various negative problems. A Commission involving the concerned representatives from the Government, Municipality, DDC, VDC and the stakeholders such as WUAs of irrigation, water supply and others has been proposed to be established. All the river conservation practices from the Government and funding agencies have to be implemented with the active participation of the beneficiaries. It must be started as early as possible. The effective way of river conservation would be the active participation of the local inhabitants with meaningful Government support.

Key words: Tinau River, conservation, riverbed materials, extraction, river health, participatory approach, Nepal

\section{Introduction}

Tinau river originates in Palpa district and flows 1 through the mountain, gorge and plains of Palpa and Rupandehi districts of Nepal. It is a class-II, perennial and third order stream (Guragain 2012; Kharel 2002). The Tinau River bifurcates into the Dano and Tinau just downstream of East-West Highway, which again meet at about $13 \mathrm{~km}$ upstream from the Indian border, and is named as Dano (JICA 1999).

The Basin area at the Nepal-India border of the Tinau River is $1,081 \mathrm{~km}^{2}$. The catchment area up to Kanyadhunga at intake point of 16/36 Irrigation System is $560 \mathrm{~km}^{2}$ The river has maximum flow during JulyAugust and minimum flow in March-April. About $75 \%$ of the annual flow of the river drains within the months of monsoon.

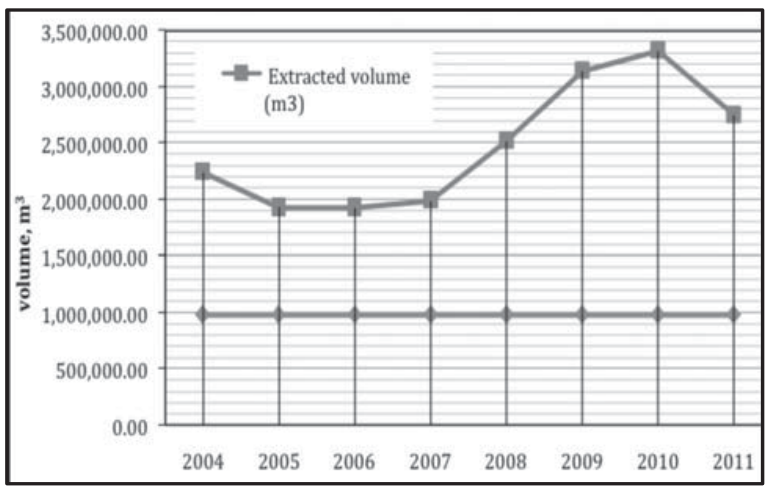

Figure 2. River-bed Extraction during Past Eight Years (2004-2011). (Source: DDC records, 2012)

There are several problems associated with the health of the Tinau River. However, the major problems associated with the Tinau are: river-bed extraction, landslides, rock-falls, mass-wasting, deforestation in the upstream catchment, over extraction of bed material downstream, river incision, flood-plain encroachment, change in geomorphology, non-regulated waste disposal, habitat destruction, effects on the intake/hydraulic structures like Bridges at Butwal and Bethari of Tinau
Rivers (Dahal et al 2012). The well foundation of the Bridge of the East-West Highway (EWH) at Butwal has been exposed by about $3 \mathrm{~m}$ in height; consequently, the diversion structure built on the Tinau river near Gadi Muhan by the Water Users' Association (WUAs) of Chaar Tapaha Irrigation System has been defunct, and similarly, the diversion structure of the SorahChhattis (16/36) Irrigation System built by WUA near Itiya Bhod also has become defunct. Earlier, the Barrage (Hattisundhe) constructed near Devinagar under the Indian Government assistance has been washed away sometime in the 1960s. Several other irrigation systems downstream managed by the farmers on either banks of the Tinau River have been defunct due to river degradation. Several electric poles erected by the Nepal Electricity Authority (NEA) along the banks of the Tinau River have deteriorated and are just hanging. Also the water level, in the substantial numbers of existing shallow tube-wells along the river banks on either side, has gone

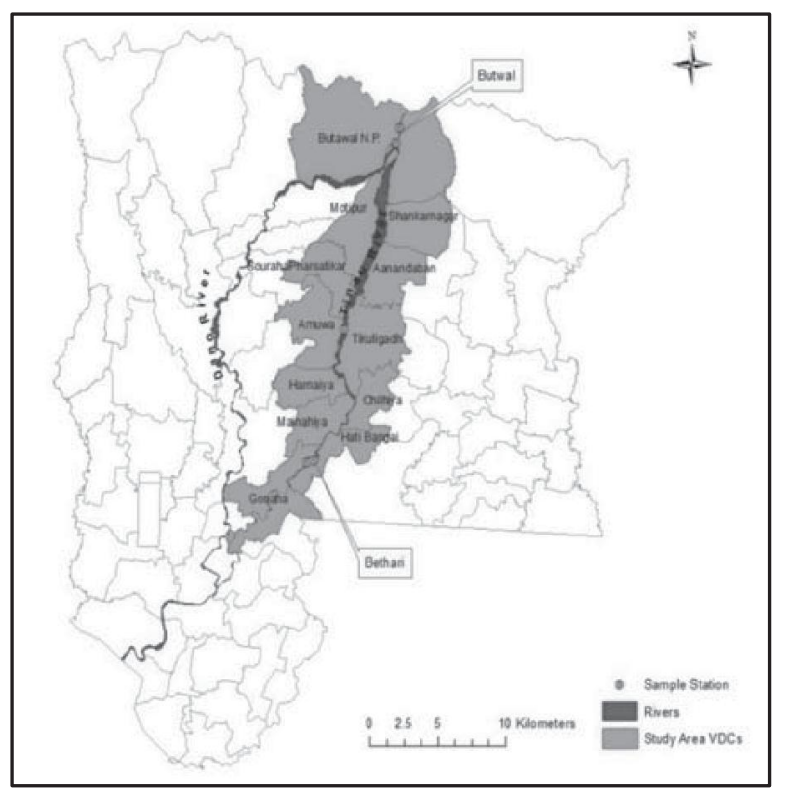

Figure 1. Map of Study Area.

HYDRO NEPAL ｜ ISSUE N0.12 ｜ JANUARY, 2013 
down affecting the productivity of the agricultural land (Guragain 2012).

River bed materials have been excessively extracted in the Tinau River over the last several years. The extraction activities of the past eight years have been presented in Figure 2. It clearly indicates that the river-bed materials were over extracted during the years 2004 to 2011.

Due to the erratic distribution of monsoon rainfall combined with the young geological formations, flashfloods are common in the basin. Moreover, human activities such as cultivation of marginal land, mining of river-bed materials, large-scale deforestation, unplanned systems of construction of physical infrastructures like roads in the hazardous mountain regions and cultivation on steep slopes have increased the incidence of landslides, increased silt in the river water causing floods in various places (PEP-5, 2009). Sedimentation, bank erosion, flooding over farm land and washout of settlements are the common features of disasters in the Tinau Basin. Every year, sand, silt and flood water covers on an average about 3,000 hectares of land of which 580 ha is covered with sand and soil (JICA 1999). With appropriate flood mitigation measures, such land could be reclaimed and soil/sand inundation could be reduced (DWIDP 2011). Because of the weak geology and unstable nature of the Churia hills, landslides in the upper catchment are frequent. During the heavy rains, the river transports high sediment load, which is deposited in its inland delta, and the gradient of the river is reduced. The sediment carrying capacity decreases upon reaching the plains, which is one of the causes of river-bank erosion and inundation.

Hence, an integrated but immediate conservation approaches are needed to conserve the health of the Tinau River. Locally, if the people are united to save the health of the river, they can raise their voice up to the top level of the government, and development can be made sustainable.

This study aims to find the most suitable conservation and protection strategies. The combined approach (government plus local effort) has been found to be the most effective at maintaining watershed and river integrity as well. Legal formation of local water conservation groups with a network of upstream and downstream groups are essential. This study is done in the same way. The study area has been selected from the source to the Indian border at Marchawar (Figure 1).

\section{Materials and Methods}

The study has been done on the basis of field observation from Butwal to Bethari, interview with key stakeholders, community people residing on the banks of the Tinau river and an interaction cum workshop with various people on "How to conserve the health of the Tinau River ?". The study was carried out during the period of November to December, 2012. A structured questionnaire was developed and interviewed with 52 persons upstream and downstream of the Tinau River. In addition to this, 10 river specialists who have already worked with the Tinau River and two from crusher industries were selected for further interview and discussion. Local social activists to conserve the health of river including journalists and local leaders were also selected for interview to know the fact of degradation of the health of the Tinau. An one day workshop cum interaction program was held at Butwal to find the overall gist associated with the health of the Tinau River. In the program, altogether 62 participants participated. Among them 4 were journalists, 5 engineers, 2 were from crusher industry, and remaining were from local water users residing on the bank of the Tinau River. In the workshop, the whole participants were divided into three groups, and they were given a set of questions based on the conservation practices. They had to find the prevailing problems and the solutions for the same.

Based on the works of the groups and their presentation, conclusion was derived from the workshop/ interaction for conservation of the health of Tinau River.

\section{Results and Discussions}

The first part of this research is quantitative research; whereas the second part is qualitative. The qualitative part of this research includes what the respondents have perceived about the devastation and conservation of the Tinau. Both results have been presented in a systematic manner as given below.

\section{Quantitative Analysis}

The local self Governance Act and Rules (1999) has provided the authority to use the local resources for development works and revenue generation. Therefore, after the enforcement of this act and rules, local bodies like the DDC, Municipalities and VDCs are extracting river-bed materials in huge quantities. However, the extraction has been indiscriminate and haphazard. Uncontrolled river-bed extraction causes change in the river morphology, downstream degradation, disturbs the natural habitat and affects aquatic animals like fishes (Kondolf 1993, 1994, 1997, 1998). There are many such symptoms observed in the Tinau River as mentioned above. The river channel is incised. The average degradation of the river channel is $3.67 \mathrm{~m}$ in a stretch of $25.54 \mathrm{~km}$. However, there is no local river conservation network. If there were a local participatory network to conserve the health of the river, the extraction could be done in a balanced way and the health of the Tinau River could be preserved.

There can be various methods of river conservation. During the survey, some of the options selected were bioengineering practices, cement masonries, gabion walls, reinforced cement concrete (RCC) structures, composite structures, etc., for the protection works to conserve the health of the Tinau River.

Among various protection works, the majority of respondents $(71 \%)$ opined that the construction of composite structures is more effective to conserve the health of the Tinau River. The health of the Tinau River 


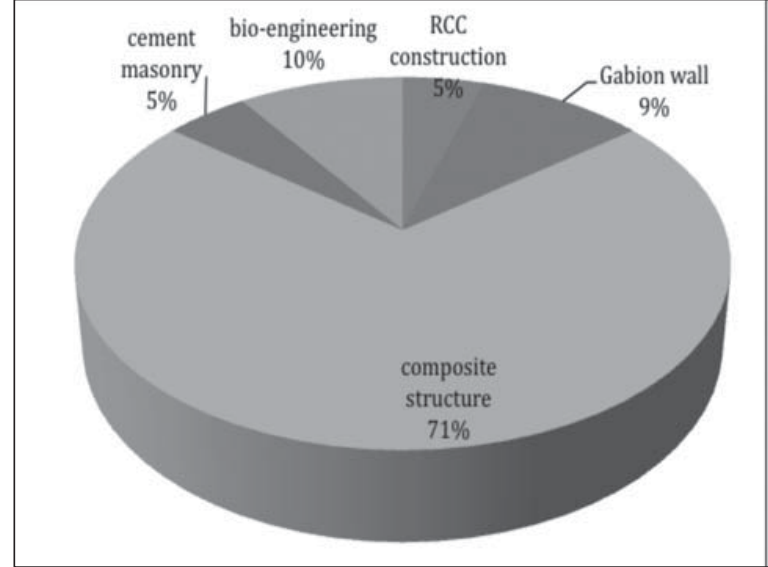

Figure 3: Practices in River Protection. (Source: Field survey, 2012)

has been regarded as highly damaged due to various causes. The Government has initiated the construction of new headworks and bed-bars so as to conserve the farmer managed irrigation systems of the Sorha- Chhatis and Chaar Tapaha (DoI 2010).

Numerous landslides are prevailing in the Tinau corridor. The remedial measures for landslide protection works could be gabion wall construction, plantation, bioengineering practices and others. However, during the survey at site, the majority of respondents (56\%) selected the bio-engineering practices for landslides protection in the Tinau corridor (Figure 4).

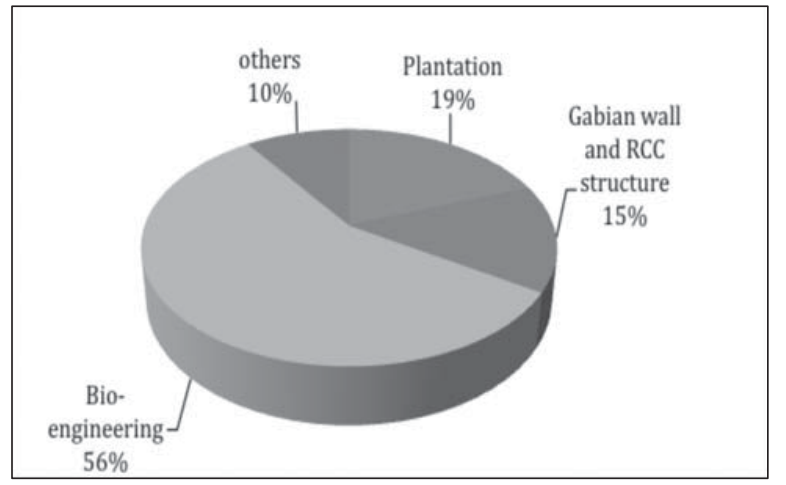

Figure 4. Structures Preferred for Landslide Protection.

(Source: Field survey, 2012)

Preventive measures for river control can be done through the government, local users' committees and in a combined way (government agency and local water users groups (Figure 5). During the survey of the site, the majority of respondents opted that the implementation works for protection should be done through the local water users' groups (75\%).

River protection works undertaken last year in the Tinau with gabion filled with boulders were not properly designed and, as a result 150m of the newly constructed gabion structures (costing Rs. 150 million) were washed out by the first flood of the Tinau. Hence, the local people have the least preferance on the gabion structure options. Further, there are substantial failure

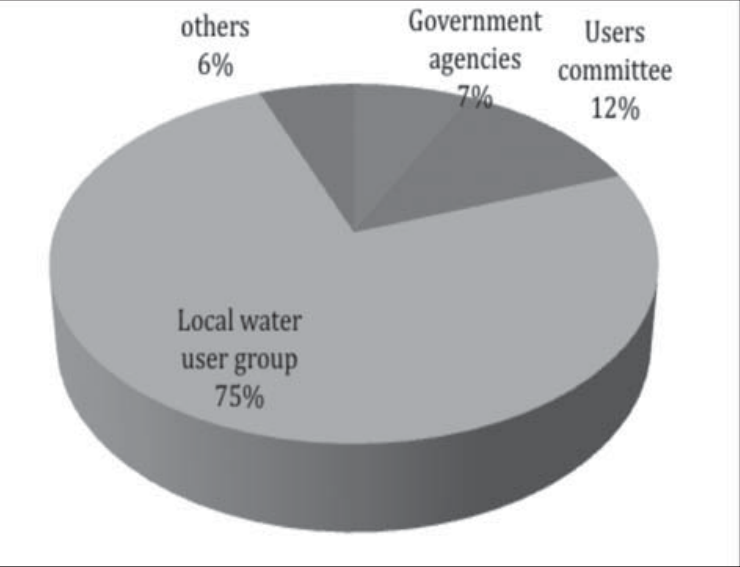

Figure 5. Agencies Involved in the Tinau Conservation. (Source: Field survey, 2012)

cases of such walls throughout the length of the river. The majority of respondents supported the composite structure option for protection works. Structures that are made by more than one material and technology are called composite structures. The composite structures in the case of the Tinau can be plantation plus cement

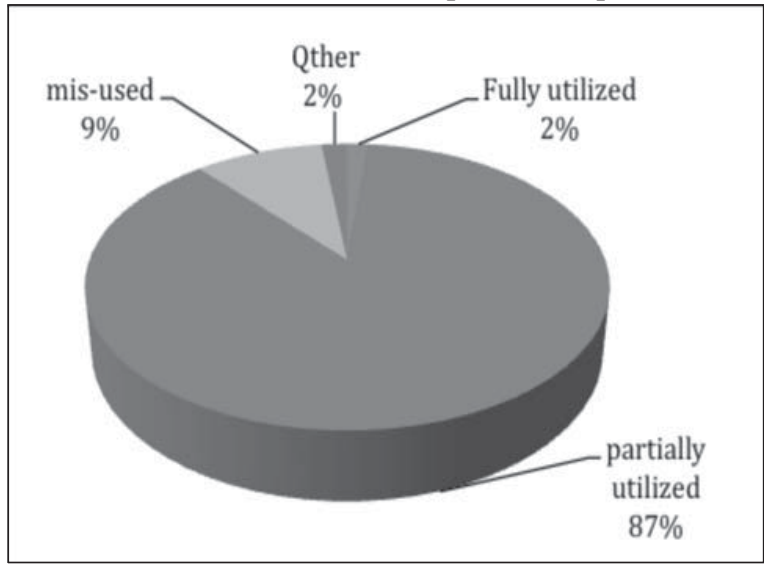

Figure 6. Utilization of Investment for the Protection Works. (Source: Field survey, 2012)

masonry, plantation plus dry masonry, plantation plus reinforced cement concrete (RCC) and so on. During the survey, the team observed the Bagmati protection works

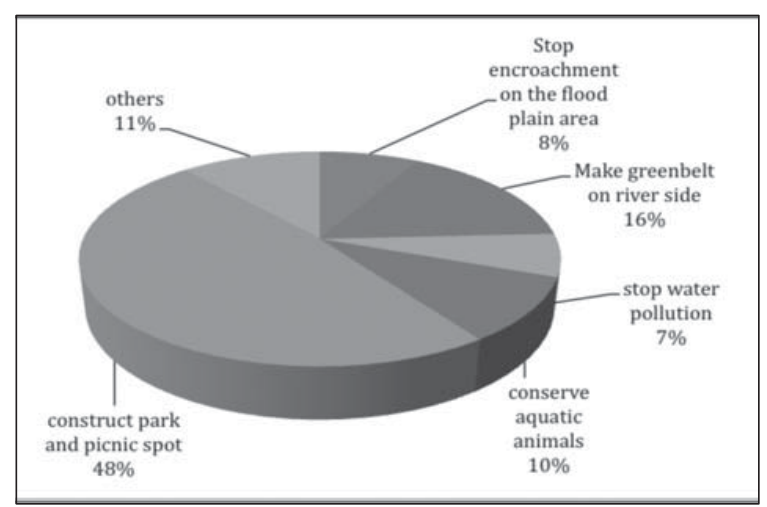

Figure 7. Infrastructure for Tourism Development. (Source: Field survey, 2012). 
at Karmaiya, Sarlahi and suggested to adopt the same method for the Tinau River as well.

People have a feeling that the water discharge in the Tinau River has been decreasing year after year. During the survey, the respondents raised serious concerns saying that that the effects of climate change, deforestation of upstream catchment, diversion of water for drinking and irrigation purposes are the major causes of declining discharge downstream.

There are several agencies investing millions of rupees year after year for protection works on the river. However, the investment has not been properly utilized (Figure 7). During the survey, the majority of respondents reported that the investment was not effectively utilized (87\%).

The river is one of the prime spots for entertainment. There is a possibility of tourism development in the Tinau corridor. During the field survey, the respondents were given several choices like prohibiting encroachment, making green belt on either side of the river, conserving aquatic animals and plants, and constructing parks and picnic spots. About $48 \%$ of the respondents selected the construction of parks and picnic spots on the floodplains (Figure 7).

\section{Qualitative Analysis}

The general rule of river conservation is to start from the source itself. During the survey at site, almost all the respondents were agreeing to conserve the health of the river from its source to the tail-end through local WUGs. The conservation practices needs an extensive study and master plan. It must mention the short-term, midterm and long-term preventive works to conserve the health of the Tinau through a network of local WUGs. Millions of rupees have been invested for years through the government agencies (Department of Irrigation, Department of water induced disaster prevention, Peoples Embankment Program, Butwal Municipality, District Development Committees, Village Development Committees, etc.) for the preservation and control of the Tinau River. However, the investment has not been effectively utilized due to the limited participation of local WUGs during construction. During the survey of the area, cent-percent of the respondents agreed with the need of the collaborative practices (Govt. + People). The protection works must be done with the network of local WUGs for the effective utilization of the investment. The active involvement of local WUGs and other stakeholders associated with the River in conserving the health of the Tinau can make the development activities more sustainable. However, the budget must be mobilized by the Government agency and monitoring role should be taken by the local people together with the Government implementing agency in a participatory manner. The joint participatory planning paradigm has been widely acclaimed as an important factor for the conservational practices. Development must be people centered. Thus, the local WUGs and other stakeholders must be compulsorily involved in all the phases of development from planning to implementation and thereafter for operation and maintenance, to make it sustainable. There is a lack of data generating and maintaining system in the Tinau basin. The hydrometeorological data must be kept in a scientific manner so as to design the hydraulic structures and to know the actual situation of the river. Hence, the hydrometeorological database system must be developed as suggested during the survey at site. The quality of river water also is not good. Furthermore, the respondents suggested that the water quality monitoring mechanism also has to be established.

Open defecation is polluting the river upstream of the intake of $16 / 36$ Irrigation System which is also a serious problem. The local bodies like VDCs, and municipality have started to stop open defecation; however, the problem is not solved. There is a lack of awareness and people's involvement in implementing the program. Thus, the anthropogenic disturbances like open defecation is still in existence. Construction and operation of public toilets may help reduce the problems.

Illegal fishing upstream and downstream of the river is rampant. Most people use poison and electric current for fishing. Thus, such type of activities must be banned and made punishable.

Similarly, there is a lack of an extensive network of local water users' groups. According to the respondents, the need of the network is an urgent task to save the health of the river. To establish a network is not a difficult task but to keep it sustainable, constant support of the Government is indispensable.

There is an urgent need of water diversion from the Kaligandaki River into the Tinau to augment water flow, wash out the pollution, irrigate the dry areas of Terai districts (Nawalparasi, Rupandehi and Kapilvastu) and generate hydro-power including other uses. As it is a mega project, at present, it is only a vision and it may take decades to implement this project.

The channel bar deposits and river terraces are major sources of riverbed material and distributed throughout the river channel under the study stretch. They were formed when the entire valley was inundated and the streams carried much of the debris as bed load material. The flood, carrying heavy sediment from the catchment area, drops down the sediments when it comes out of the gorges to the plains at nearby Butwal city (Sharma 1997).

The People's Embankment Program (PEP 2009) prepared a Detailed Project Report (DPR) in 2009 from Butwal to Marchawar for the conservation of the Tinau River. The study focused mainly on general information of the river hydrology, socio-economic condition of the area, existing condition of the river and proposed remedial measures. However, it could not be implemented in a proper way.

The construction materials extracted from the Tinau River are being exported to India. The undulated riverbed along the course or many man-made ditches, which 
do not fill up after the main flood, show that there is a clear deficit in sediment deposition as compared to the present mining rate. If the situation continues, there could be a problem of river-bed lowering, which affects riverbank erosion causing damage to the bridges, embankment protection, and intake of the canal in the upstream side. It can also damage all man-made structures (especially hydraulic structures) (Butwal Municipality 2001). People living in the periphery of Butwal city raised their voice to protect the river and a case was filed in the Supreme Court. The court ordered to stop the extraction activity in the Tinau. The delegation from the house of representatives visited the site and made a report concerning the degradation of river environment (Parliament 2010).

An Environmental Impact Assessment (EIA) study report was prepared by the DDC (Rupandehi) to continue the extraction activities in the Tinau River. The report mentions that the environment of the Tinau River is continuously deteriorating due to water pollution and deforestation.

Human activity is one of the main causes for such adverse impacts on the aquatic ecosystem. The extraction has caused a lot of loss of aquatic lives. Thus, the Tinau needs rehabilitation measures such as establishment of predestined areas for extraction of boulders, sand and aggregates from the river (DDC 2011).

Fresh water bodies like the Tinau and others are also sources of drinking water. Many people of Butwal municipality are taking drinking water from the Tinau River. There is a need of water quality monitoring in the River. The biological water quality monitoring is considered one of the best methods for the rivers like the Tinau (Sharma 1996).

River processes refer to the interaction between water and sediment. The capability of the water in the river to transport the sediment supplied to it determines the dominant river processes for a specific reach of river. If there is an imbalance between the supply and transport capacity, the river will adjust its hydraulic characteristics of width, depth, slope, and pattern by the process of aggradation (deposition), degradation and/or lateral shifting (WECS 1987).

Establishing appropriate natural resources management institutions and strengthening the capacity of these institutions could help in the efficient and equitable distribution of these resources to the beneficiaries (Guragain 2012). Such institutions would contribute to increase the economic status of the nation. These institutions are also important to avoid and manage conflicts and ensure the participation of targeted people.

\section{Conclusion}

The Tinau River needs extensive planning to restore and conserve its health. The conservation approaches are of various types. However, the local initiative to conserve the health of the river is felt effective in case of the Tinau. The combined efforts of the agency and related stakeholders and water users' groups could be the best way of river conservation. If the local initiatives were commenced in a proper manner and government provided the necessary support to them, the river conservation practices could be made sustainable.

The Workshop attended by the related stakeholders shows a clear determination to counteract the negative aspects and make Tinau River a healthy river. Even though, the workshop has not come up with a methodology of creating a River Commission, it could be a starting point to move forward. Such workshops and interaction programs are needed in the future too.

The main suggestions for the conservation of the health of the Tinau given by the participants of the Workshop are summarized as follows:

- Stop encroachment on the flood plain area,

- Make green-belt on both sides of the Tinau river,

- Stop water pollution,

- Conserve aquatic plants and animals,

- Construct embankments on either side of the Tinau river and make a motorable road,

- Prepare proper waste management plan and stop waste disposal into the Tinau river channel and flood-plains, construct electric incinerator for the cremation of dead bodies,

- Restrict uncontrolled river-bed extraction,

- Regulate river-bed material export to India, and

- Establish a network of local water users' groups for river conservation and establish powerful Commission which will include Govt. agencies also on for the conservation of the River.

- Construct parks and picnic spots,

- Demarcate the actual river width in the topographic map,

- provide compensation to who are already settled on the bank and flood plains of the Tinau and resettle them,

- Undertake Initial Environmental Examination (IEE) or Environmental Impact Assessment (EIA),

- However, the holistic conservation techniques through participatory approaches are lacking. Therefore, there is an urgent need of local initiatives to conserve the health of the Tinau River and make its development sustainable.

\section{Acknowledgements}

We would like to thank Professor Dr. Subodh Sharma for the preliminary correction for improvement of the manuscript and Mahesh Pathak for providing us the GIS map.

Khet Raj Dahal, PhD is a student of Kathmandu University. He completed his Master of Science in Engineering from University of Architecture and Civil Engineering, St. Petersburg, Russia, 1993; Master in Sociology from Tri-Chandra College, Tribhuvan University, 1999 and Master of Science in Ecology and 
Environment from Sikkim Manipal University, 2005. He has been working in different field of engineering including professional teaching for 20 years. He is the winner in Best writing on environment for the conservation of nature and natural resources from Lumbini Zone in 2005 given by Save the Environment in Rupandehi.

Corresponding address: dahal.khetraj@gmail.com

Hari Prasad Guragain B.E (Civil), 201O, M.Sc. (Construction Management) 2012, has total experience of 24 years in engineering (civil). He is an expert of irrigation management and river protection works. Currently, he is a Sub Division Chief in Udaypur district, Nepal.

\section{References}

Baidya, H., 2003, Twelve years struggle for the conservation of Bagmati River. Nepal Water Conservation Foundation, Kathmandu.

Butwal Municipality, 2001, Save the Tinau. Report prepared by Nepal Engineers' Association, Lumbini Regional Centre, Butwal.

Dahal K. R., S. Sharma, C. M. Sharma, 2012, A review of riverbed extraction and its effects on aquatic environment with special reference to Tinau river, Nepal. HYDRO-Nepal, Journal of Water, Energy and Environment, Issue No.11, pp. 49-56.

DWIDP, 2011, Feasibility Study for Tinau Integrated Development Project. Report prepared by Environment and Resource Management Consultant (ERMC) and submitted to Department of Water Induced Disaster Prevention, Kathmandu, Nepal.

DDC, 2011, Environmental Impact Assessment. Draft Report of Tinau, Dano, Rohini and Kanchan Rivers. District Development Committee, Rupandehi, Nepal.

Dixit, A. and D. Gyawali, 1999, Fractured institutions and physical interdependence, challenges to local water management in the Tinau River Basin, Nepal, pp. 58-121 in Rethinking the mosaic, investigations into local water management, Nepal Water Conservation Foundation.

Department of Irrigation (DOI), 2010, Project Report for the construction of head works in Chaar Tapaha and SorhaChhatis Irrigation canal. Prepared by a DoI, 2009.

Guragain, H., 2012, Impacts on Hydraulic Structure due to Riverbed Extraction. Thesis Submitted to Lumbini Engineering College, Pokhara University, Nepal.

Gurung, S., 2012, High altitude aquatic biodiversity of Gokyo Lake series in Sagarmatha National Park, Nepal. A PhD dissertation submitted to Kathmandu University, Nepal.

Japan International Co-operation Agency (JICA), 1999, The Study on Flood Mitigation Plan for selected Rivers in the Terai plain in the Kingdom of Nepal, Vol. III. Report, Prepared by Nikken Consultants, Inc., Nippon Koei Co. Ltd.

Jha, B.R., 2006, Fish ecological studies and its application in assessing ecological integrity of rivers in Nepal.
Thesis submitted to department of environmental science and engineering. Ph.D. Thesis: Kathmandu University, Nepal.

Khanal, Sanjay Nath, 2001, Effects of Human Disturbances in Nepalese Rivers on the Benthic Invertebrate Fauna. PhD Thesis: University of Agricultural Sciences (BOKU), Vienna.

Kharel, L. N., 2002, Description of the Tinau River. Institute of Engineering, Pulchowk Campus, Tribhuvan University, Nepal.

Kondolf, G. Mathias, 1994, Environmental Planning in Regulation and Management of In-stream Gravel Mining in California. Landscape and Urban planning 29 (1994), pp 185-199.

Kondolf, G. Mathias, 1997, Hungry Water: Effects of Dams and Gravel Mining on the River Channels. Environmental Management vol. 21 no. 4, pp 533-551.

Kondolf, G. Mathias, 1998, Environmental Effects of Aggregate Extraction from river channels and floodplains. Aggregate Resources a Global perspective, pp 113-129.

Kondolf, G. Mathias, 1993, Geomorphic and Environmental Effects of In-stream Gravel Mining. Landscape and Urban planning vol. 28, pp 225-243.

Local Self-Governance Act, 1999, Government of Nepal, Ministry of Law, Justice and Parliamentary Affairs.

Local Self-Governance Rules, 1999, Government of Nepal, Ministry of Law, Justice and Parliamentary Affairs.

Parliament (House of Representatives of Nepal), 2010, Decisions collection from the parliamentary committee, committee for the distribution of natural resources, Singh Durbar, Kathmandu, Nepal.

Paudel, Uttam, 2011, Flood plain analysis and vulnerability assessment of Tinau Khola watershed, Nepal. A dissertation submitted to the department of environmental science, T U, Kirtipur.

People's Embankment program (PEP), 2009, Detailed Project Report for Tinau Conservation through the construction of embankment, from Butwal to Marchawar. Ministry of Irrigation, Department of water induced disaster prevention, People's Embankment Program, Field office, Butwal, Nepal.

Sharma S., 1996, Biological water quality monitoring of water in the rivers of Nepal. PhD thesis submitted to university of agriculture, forestry and renewable natural resources, Vienna, Austria.

Sharma, C.M., 1996, Study on the fish biodiversity and fishery resources of the Tinau River. M.Sc. Thesis Submitted to the Central Department of Zoology, Tribhuvan University, Nepal.

Sharma, C.K., 1997, a treatise on Water Resources of Nepal. Ms Sangeeta Sharma, Bishal Nagar, Kathmandu.

USEPA, 1995, Rapid bio-assessment protocols for use in streams and wade-able rivers. United States Environmental Protection Agency.

WECS, 1987, Erosion and sediment in the Nepal Himalaya. Water and Energy Commission Secretariat (WECS). 


\section{PHOTOGRAPHS OF THE SITE}

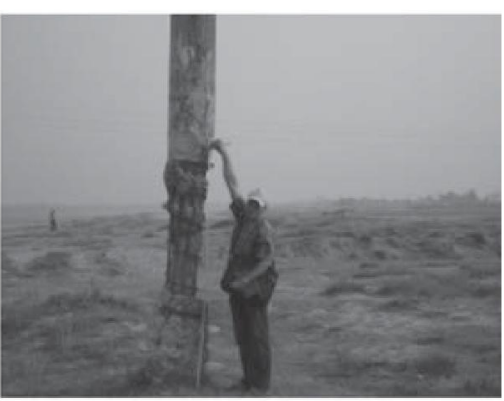

Figure 8. Electric pole hanging

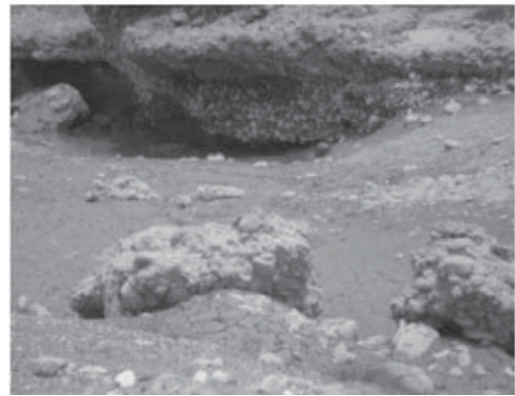

Figure11. Cave formation

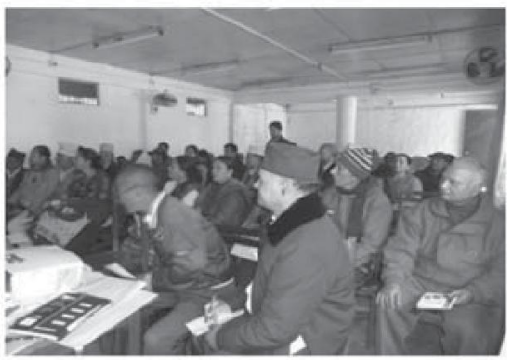

Figure 14. Interaction with locals

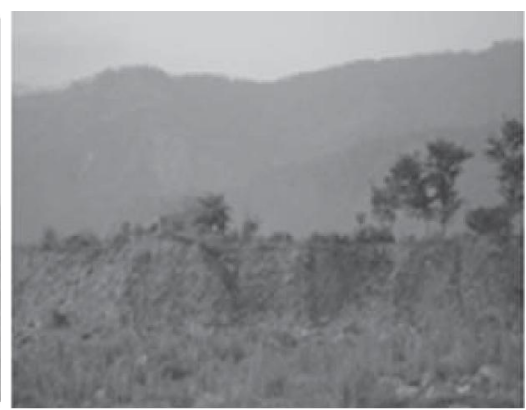

Figure 9. Bank breaching

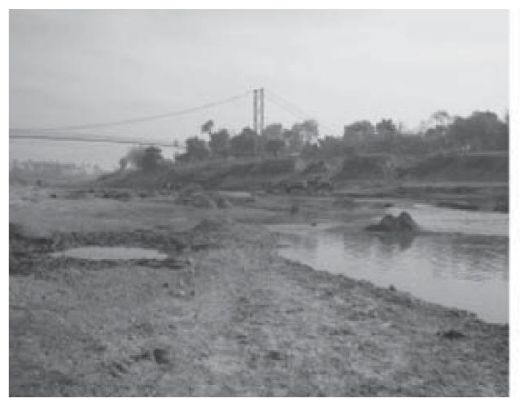

Figure 12. Habitat destruction

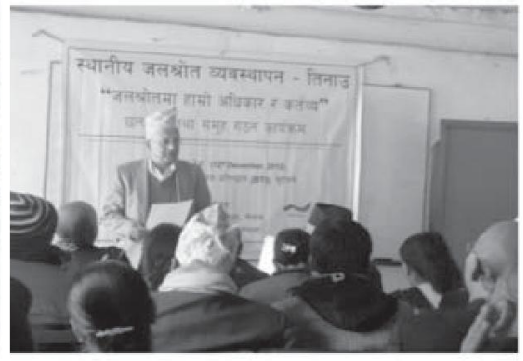

Figure 15. Explanation by River Expert (Source of above photos: Field Survey, 2012)

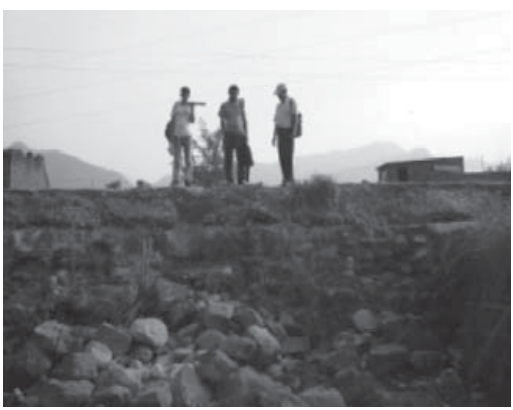

Figure.10. Protection failure

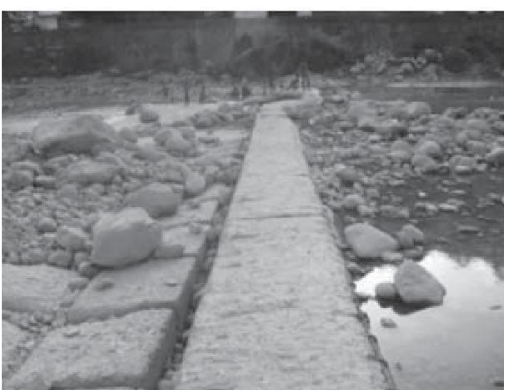

Figure 13. Protection work

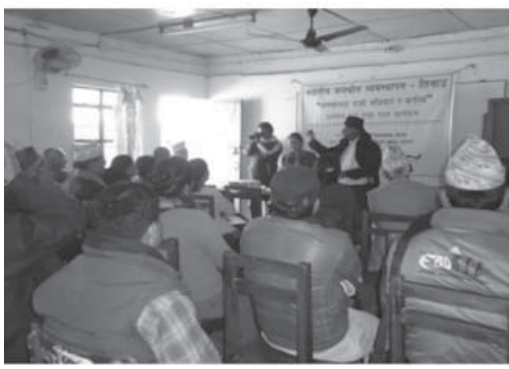

Figure 16. Presentation by the Leader

\section{CALENDAR OF EVENTS - ENVIRONMENT}

20-21 February, 2013: UNECE Meeting of the Core Group of Pilot Projects on Climate Change. Location: Geneva, Switzerland. More info: http://www.unece. org/env/water/core_group_pilot_projects_climate_ chang...

20-22 February, 2013: Regional Workshop on Payment for Ecosystem Services in the HKH region. Location: ICIMOD Headquarters. http://www. icimod.org. Contact Person Laxman Joshi.

24-25 February, 2013: 3rd International Conference on Future Environment and Energy (ICFEE) Conference. Location: Rome, Italy. More info: http:// www.icfee.org/

24-27 February, 2013: International Conference on Natural Resources Management in a Changing World. Location: Al-Ain, United Arab Emirates.
Contact Email: NRMConference@uaeu. ac.ae. More info: http://www.fos.uaeu.ac.ae/ conference/nrm/

6-8 March, 2013: Expert Consultation on Knowledge and Capacity Needs for Sustainable Development in Post-Rio+20 Era. Location: Incheon, Republic of Korea. More info: http://www.unosd.org/index.php ?page $=$ view\&type $=13 \& n r=9 \& m e n u=229$

14-16 March, 2013: International Conference on Global Scenario in Environment and Energy. Location: Bhopal, Madhya Pradesh, India. More info: http://www.icgsee2013.com

19-22 March, 2013: World Environmental and Water Resoureces Congress 2013. Location: Cincinnati, USA. Contact Email: lking@asce.org. More info: http://content.asce.org/conferences/ewri2013/ 